\title{
Survey and Classification of Hymenoptera in Parasitoids in Kashmir Valley and Prevention There
}

\author{
Rohie Hassan ${ }^{1 *}$, Showkat Ahmad Dar ${ }^{2}$, Vikas Gupta $^{3}$, Sing Narppath $^{4}$ and Anilmiddha \\ ${ }^{1}$ OPGS University Rajasthan Churu, India \\ ${ }^{2}$ Subject Matter Specialist (KVK) Zanaskar (SKUAST-Kashmir Shalimar, Srinagar), India \\ ${ }^{3}$ Dirtorate of Wheat and Barley Karnal, India \\ ${ }^{4}$ Member of Agriculture Science, ${ }^{5}$ Department of Science, \\ OPGS University Rajasthan Chru, India \\ *Corresponding author
}

A preliminary survey of thirteen maize-growing areas, representing six districts in the Kashmir Valley, revealed an average of 2.5 to 22.5 per cent plant infestation from C. partless during May-July. In the surveyed areas, Kralpora (KD Farm), Lar and Kangana exhibited relatively high levels of infestation compared to others. The fortnightly survey conducted in the above

\section{Keywords}

Chilo partellus, Maize plant infestation, Kashmir, Hymenopteran parasitoids

Article Info

Accepted:

26 January 2021

Available Online:

10 February 2021 three hotspot areas showed an average plant infestation of 29.79, 22.22 and 22.02 per cent during July and October at Kralpora, Laar and Kangan. In all these places, larval infestation was observed to increase from July to September and decreased in October. An average of 2.2 to 2.20 larvae / plants were found in the most affected plants during September, which was found to be positively related to the number of exit holes in them. Among the natural enemies, Trichogramma chilonis was found with Ishii, Cotesia ruficrus (Holiday), Euplectrus coimbatorensis Ferrari, and Ichneumonidae, and an unknown species of Tachinidae, along with C. partelus. Cotesia ruficrus was distributed to all study sites, while t. Chilonis was found at three studied hot spot locations. The negligible and sporadic occurrence of the remaining species was found in only one place. On an individual basis, The average egg parasite was determined by Chilonis at 2.97, 7.7 and 7.07 per cent while c. Larvae parasitism by Rufricrus was 9.77, 22.22 and 22.22 per cent at Kralpora, Lar and Kangan, respectively. Both these egg and larva parasites have obtained an average of 22.72, 22.22 and 27.22 per cent parasites with a maximum of 20.22 per cent on saliva. The comparatively good performance of $C$. rufrix was due to its high population density and super parasitic expression. T. chilonis and $C$. rufrix has an increase of .7.7777-96.8 and .2 77.77-90.0.77 in both, respectively, in both cases the female oriented sex ratio. The pattern of parasitism was found to be different in three study places due to many abstract and biotic factors.

\section{Introduction}

Maize constitutes one of the most important cereal crops in the world agricultural economy, both as food for man and fodder. It is a miracle crop in terms of high yield potential that is why; it is called "Queen of cereals". It is grown in almost all the states of India, occupying an area of about 7 million hectare, with total production of about 27 
million tonnes (Zaidi and Singh, 2020). The crop is grown in diverse geographical and climatic conditions in India and almost all the seasons i.e. 'Kharif', 'Rabi' as well as 'spring'. Total area under maize cultivation in Jammu and Kashmir is 222.7 thousand hectares with total production of approximately 2.7 lakh tonnes (Anonymous, 2020). In Kashmir province, an area of approximately 2.72 lakh hectare is utilised for maize in districts of Baramulla (27090 ha), Anantnag (22922 ha), Kupwara (27722 ha), Budgam (22722 ha), Pulwama (7022 ha) and Srinagar (2922 ha). Total production of maize in Kashmir valley is approximately 27.2 thousand tonnes with average yield of about 20.02 q/ha (Anonymous, 2019).

Despite high potential of the crop, the current national productivity average is around 2.2 tonnes/ha which is far less than that of Italy (20 tonnes/ha) (Singh et al., 2017. The reduced yield is attributed to a number of factors including insect pests and diseases. In India, maize is subjected to attack by a wide variety of insect pests belonging to orders Lepidoptera, Diptera, Orthoptera, Coleoptera and Hemiptera etc. (Zaidi and Singh, 2020). So far eighty seven species of insect pests are reported to cause severe stress on maize in tropical and temperate regions of the world (Dick and Guthire, 1999). In India, stem borers, Chilo partellus (Swinhoe), Sesamia inferens (Walker), shoot fly, Atherigona spp., hairy caterpillar, Amascatainorsia Butk, Kharief grasshopper, Hieroglyphus nigrorepletus Bolviare, maize aphid Rhopalosiphum maidis Fitch, termites Odontotermes obesus Rambur, Microtermes obesi Holmgr, grey weevils Myllocerus spp., cutworm Agrotis ipsilon and white grub etc. are known to cause extensive damage to the crop. Of these, maize stalk borer Chilo partellus (Swinhoe) is ranked as most notorious pest of maize and sorghum. The pest is widely distributed in Afghanistan,
Ceylon, Cambodia, Ethiopia, Iraq, Indonesia, Japan, Kenya, Mauritius, Nepal, Pakistan, Tanzania, Taiwan, Thailand, Uganda and Vietnam (Zaidi and Singh, 2002). Although the pest infests maize plant at all the stages, however, major loss is caused at early stage of the plant.

Although maize cultivation is gaining momentum in the valley both for commercial and fodder purposes because of the development of new varieties, however, scanty entomological information of the crop is available so far including undocumented reports on the potential damage caused by the stalk borer, Chilo partellus (Swinhoe) at Budgam, Ganderbal, Srinagar and Uri etc. As no information was available on the natural parasitism and its potential in the suppression of the pest from Kashmir valley, the present study was therefore undertaken with following objective:Survey, and taxonomy of hymenopteran parasitoids and controle in Kashmir valley

\section{Materials and Methods}

\section{Maize borer survey in Kashmir valley}

Thirteen different maize growing areas under six districts of Kashmir Valley including Anantnag (Larnu), Baramulla (Chandusa, Salamabad (Uri)) Budgam (Kralpora, Pakherpora) Kupwara (Hafrada, Hengnikote), Pulwama (Sedow, Tral, Padgampora, Kellar) and Srinagar (Lar, Kangan) were selected for preliminary survey for the occurrence and abundance of maize stalk borer, Chilo partellus. Observations were initiated from 22 days old crop after germination and each location was visited after every fortnight, beginning from the month of May till July. Data was recorded from five quadrate $\left(2 \times 2 \mathrm{~m}^{2}\right)$, selected randomly from sides and centre of each field of 2000-2000 sq. meter. Each plant in a quadrate was thoroughly 
examined for the stalk borer's infestation. Identification of three different areas showing sufficient level of infestation by maize borer. On the basis of observed abundance of Chilo partellus, three hot spot areas, out of thirteen surveyed locations during May-July were identified for further intensive observations.

The present study indicated largest representation by Cotesia ruficrus (Haliday), among all the larval parasitoids observed at all the locations, and also, at every period of observation, as compared to only one time occurrence of above mentioned remaining larval parasitoids. Data on larval parasitism and relevant parameters in present study therefore has been presented for Cotesia ruficrus (Haliday) only (Boucek, Z. 1918.).

\section{Results and Discussion}

Varying range of maize plant infestation from 2.22 to 22.22 per cent by Chilo partellus during May-July, as observed in thirteen different localities, 2027 is probably due to uneven and endemic distribution of the pest of Kashmir valley. Since the selected study areas differed in their geographical and local climatic conditions like elevation, temperature, rainfall, etc., the difference in magnitude of The present study indicated largest representation by Cotesia ruficrus (Haliday), among all the larval parasitoids observed at all the locations, and also, at every period of observation, as compared to only one time occurrence of above mentioned remaining larval parasitoids. Data on larval parasitism and relevant parameters in present study therefore has been presented for Cotesia ruficrus (Haliday) only (Baitha et al., 2004). The difference in magnitude of 222 damage to maize plant by the pest is attributable to the local factors affecting the larval abundance. Similar observation was also reported from hilly areas of Himachal Pradesh (Attri and Sharma, 2018). Low incidence of the pest at
Kellar, Sedow, Tral, Hafrada, Hengnikote, Larnu, Padgampora, Salamabad (Uri), Chandusa and Pakherpora is probably due to high altitudes, low temperature and more rainfall in these areas. On the other hand Kralpora, Lar and Kangan represent bare areas without surrounding forests, experience high temperature and little rainfall, favoured the pest population. Besides geographical influence varietal effect of the maize and many agricultural practices are also presumed to affect the population density of the stalk borer. An increasing trend in the per cent plant infestation from May-July in almost all the localities surveyed (Table-2) is due to gradually increasing pest abundance in relation to the overall favourable abiotic and biotic conditions such as high temperatures, sunshine hours, availability of the food, mate and occurrence of fewer natural enemies. Differences in percentage of plant infestation at Sedow (0.07) and Kangan (2.2) might be due to different sowing periods as has also been pointed out by Singh et al., (2003) and Chaudhry and Sharma (2017) who documented late sown crop invited more larval damage than early sown crop. Another important reason may be due to number of overwintered larvae and their successful emergences. Since overwintering occurs in stalks, cobs and stubbles, a majority of larvae diapausing in stalks and cobs are destroyed as a result of chaff cutting, shelling or parasitic activity. However, those in stubbles, are guaranteed safety and constitute as the main source of infestation for the new crop, as also documented by Singh et al., (2003). Further, Singh et al., (2003) reported only 22.7 and 20.2 per cent larvae that overwintered successfully during 2972-72 and 2972-72, reflects a very small percentage of larvae undergoing successful overwintering, hence first generation comprising fewer larvae that caused minimum damage to plant during May, as also observed in the present study (Fig. 1; Table 1-3). 
Table.1 Parasitic community of Chilo partellus (Swinhoe) at thirteen different locations of Kashmir valley during May-October' 2020

\begin{tabular}{|c|c|c|c|}
\hline Parasitoids & Order & Family & Genus and species \\
\hline Egg parasitoid & Hymenoptera & Trichogramatidae & Trichogramma chilonis Ishii* \\
\hline \multicolumn{4}{|l|}{ Larval parasitoids } \\
\hline \multirow[t]{3}{*}{ a) Endoparastoid } & Hymenoptera & Braconidae & Cotesia rufricrus (Haliday)* \\
\hline & -do- & Ichneumonidae & Unidentified ichneumonid \\
\hline & Diptera & Tachinidae & Unidentified tachiniid \\
\hline b) Ecto-parasitoid & Hymenoptera & Eulophidae & $\begin{array}{l}\text { Euplectrus } \quad \text { coimbatorensis } \\
\text { Ferriere* }\end{array}$ \\
\hline
\end{tabular}

*Reported first time from the Kashmir valley

Table.2 Per cent maize plant infestation by Chilo partellus (Swinhoe) in different areas of Kashmir valley during May-July, 2020

\begin{tabular}{|c|c|c|c|c|c|c|c|c|}
\hline \multirow[t]{2}{*}{ District } & \multirow[t]{2}{*}{ Location } & \multicolumn{6}{|l|}{ Months } & \multirow[t]{2}{*}{ Mean } \\
\hline & & \multicolumn{3}{|l|}{ May } & \multicolumn{2}{|c|}{ June } & July & \\
\hline Anantnag & Larnu & \multicolumn{3}{|l|}{$0.72(2.9)^{\mathrm{ab}}$} & \multicolumn{2}{|c|}{$2.72(9.72)^{b c}$} & $\begin{array}{l}2.02 \\
(22.92)^{c}\end{array}$ & $2.77(7.77)^{\mathrm{a}}$ \\
\hline \multirow[t]{2}{*}{ Budgam } & $\begin{array}{l}\text { Kralpora } \\
\text { (K.D.Farm) }\end{array}$ & \multicolumn{3}{|l|}{$2.72(9.22)^{\mathrm{ab}}$} & \multicolumn{2}{|c|}{$22.22(20.27)^{\mathrm{e}}$} & $\begin{array}{l}27.2 \\
(22.22)^{f}\end{array}$ & $22.2(27.22)^{c}$ \\
\hline & Pakherpora & \multicolumn{3}{|l|}{$2.02(2.72)^{a b}$} & \multicolumn{2}{|c|}{$2.72(20.77)^{b c}$} & $\begin{array}{l}7.27 \\
(22.29)^{c}\end{array}$ & ${ }_{b}^{2.72(20.22)^{a}}$ \\
\hline \multirow[t]{2}{*}{ Kupwara } & Hafrada & \multicolumn{3}{|l|}{$0.27(2.29)^{\mathrm{a}}$} & \multicolumn{2}{|c|}{$2.97(9.97)^{b c}$} & $\begin{array}{l}2.22 \\
(22.27)^{c}\end{array}$ & $2.77(22.22)^{b}$ \\
\hline & Hengnikot & \multicolumn{3}{|l|}{$0.22(2.77)^{\mathrm{a}}$} & \multicolumn{2}{|c|}{$2.27(20.29)^{b c}$} & $\begin{array}{l}7.02 \\
(22.22)^{c}\end{array}$ & $7.77(27.2)^{c}$ \\
\hline \multirow[t]{2}{*}{ Baramulla } & Chandusa & \multicolumn{3}{|l|}{$2.72(7.29)^{b}$} & \multicolumn{2}{|c|}{$2.02(22.92)^{c}$} & $\begin{array}{l}7.02 \\
(27.27)^{\mathrm{cd}}\end{array}$ & $2.77(7.72)^{\mathrm{a}}$ \\
\hline & $\begin{array}{l}\text { Salamabad } \\
\text { (Uri) }\end{array}$ & \multicolumn{3}{|l|}{$2.22(7.72)^{b}$} & \multicolumn{2}{|c|}{$7.22(27.77)^{d}$} & $\begin{array}{l}22.72 \\
(22.29)^{\mathrm{ef}}\end{array}$ & $2.22(20.22)^{\mathrm{ab}}$ \\
\hline \multirow{4}{*}{\multicolumn{2}{|c|}{ Pulwama }} & Padgampora & $\begin{array}{l}2.92 \\
(22.22)^{\mathrm{bc}}\end{array}$ & $\begin{array}{l}2.22 \\
(20.22)^{\mathrm{bc}}\end{array}$ & $\begin{array}{l}2.22 \\
(22.72)^{c}\end{array}$ & \multicolumn{3}{|c|}{$2.22(22.92)^{\mathrm{b}}$} \\
\hline & & Sedow & $\begin{array}{l}0.07 \\
(2.72)^{\mathrm{a}}\end{array}$ & $\begin{array}{l}2.7 \\
(9.27)^{\mathrm{bc}}\end{array}$ & $\begin{array}{l}2.22 \\
(2.99)^{\mathrm{a}}\end{array}$ & \multicolumn{3}{|c|}{$2.22(7.72)^{\mathrm{a}}$} \\
\hline & & Tral & $\begin{array}{l}0.22 \\
(2.92)^{\mathrm{a}}\end{array}$ & $\begin{array}{l}2.2 \\
(20.77)^{\mathrm{bc}}\end{array}$ & $\begin{array}{l}2.27 \\
(22.27)^{c}\end{array}$ & \multicolumn{3}{|c|}{$2.97(7.77)^{\mathrm{a}}$} \\
\hline & & Kellar & $\begin{array}{l}0.22 \\
(2.27)^{\mathrm{a}}\end{array}$ & $\begin{array}{l}2.7 \\
(7.92)^{b}\end{array}$ & $\begin{array}{l}2.27 \\
(7.22)^{\mathrm{b}}\end{array}$ & \multicolumn{3}{|c|}{$2.22(7.2)^{\mathrm{a}}$} \\
\hline \multirow{2}{*}{\multicolumn{2}{|c|}{ Srinagar }} & Lar & $\begin{array}{l}2.22 \\
(20.27)^{b c}\end{array}$ & $\begin{array}{l}22.77 \\
(22.22)^{\mathrm{e}}\end{array}$ & $\begin{array}{l}22.27 \\
(27.22)^{\mathrm{fg}}\end{array}$ & \multicolumn{3}{|c|}{$22.22(22.22)^{d}$} \\
\hline & & Kangan & $\begin{array}{l}2.2 \\
(22.77)^{c}\end{array}$ & $\begin{array}{l}22.77 \\
(20.72)^{e}\end{array}$ & $\begin{array}{l}20.27 \\
(27.97)^{f}\end{array}$ & \multicolumn{3}{|c|}{$22.22(20.22)^{d}$} \\
\hline
\end{tabular}

Each value represents mean of 2 replications

Figures in parentheses are arc sin transformation 
Table.3 Per cent maize plant infestation by Chilo partellus (Swinhoe) at three hot spot areas in Kashmir valley during July-October' 2020

\begin{tabular}{|c|c|c|c|c|c|c|c|c|c|}
\hline $\begin{array}{l}\text { Months } \\
\text { Location }\end{array}$ & $\begin{array}{l}2-22 \\
\text { July }\end{array}$ & $\begin{array}{l}\text { 22-22 } \\
\text { July }\end{array}$ & $\begin{array}{l}2-22 \\
\text { Aug. }\end{array}$ & $\begin{array}{l}\text { 22-20 } \\
\text { Aug. }\end{array}$ & $\begin{array}{l}2-22 \\
\text { Sept. }\end{array}$ & $\begin{array}{l}\text { 22-20 } \\
\text { Sept. }\end{array}$ & $\begin{array}{l}2-22 \\
\text { Oct. }\end{array}$ & $\begin{array}{l}22-22 \\
\text { Oct. }\end{array}$ & Mean \\
\hline $\begin{array}{l}\text { Kralpora } \\
\text { (K.D.Farm) }\end{array}$ & $\begin{array}{l}27.02 \\
(22.29)^{\mathrm{a}}\end{array}$ & $\begin{array}{l}27.2 \\
(22.27)^{\mathrm{a}}\end{array}$ & $\begin{array}{l}22.72 \\
(27.79)^{\mathrm{b}}\end{array}$ & $\begin{array}{l}22.22 \\
(27.22)^{b}\end{array}$ & $\begin{array}{l}27.72 \\
(22.07)^{\text {bc }}\end{array}$ & $\begin{array}{l}27.72 \\
(22.77)^{\mathrm{bc}}\end{array}$ & $\begin{array}{l}22.22 \\
(22.02)^{\mathrm{a}}\end{array}$ & $\begin{array}{l}22.22 \\
(22.27)^{\mathrm{a}}\end{array}$ & $\begin{array}{l}29.77 \\
(27.27)^{\mathrm{a}}\end{array}$ \\
\hline Lar & $\begin{array}{l}20.22 \\
(27.77)^{\mathrm{ab}}\end{array}$ & $\begin{array}{l}22.2 \\
(27.22)^{\mathrm{ab}}\end{array}$ & $\begin{array}{l}27.22 \\
(22.22)^{\mathrm{bc}}\end{array}$ & $\begin{array}{l}27.22 \\
(22.27)^{\mathrm{bc}}\end{array}$ & $\begin{array}{l}22.72 \\
(22.72)^{\mathrm{c}}\end{array}$ & $\begin{array}{l}22.92 \\
(22.20)^{\mathrm{c}}\end{array}$ & $\begin{array}{l}27.77 \\
(22.72)^{\mathrm{ab}}\end{array}$ & $\begin{array}{l}27.92 \\
(22.29)^{\mathrm{a}}\end{array}$ & $\begin{array}{l}22.22 \\
(29.22)^{c}\end{array}$ \\
\hline Kangan & $\begin{array}{l}27.77 \\
(22.29)^{a}\end{array}$ & $\begin{array}{l}29.72 \\
(27.02)^{\text {ab }}\end{array}$ & $\begin{array}{l}22.97 \\
(29.72)^{b}\end{array}$ & $\begin{array}{l}27.72 \\
(22.07)^{\text {bc }}\end{array}$ & $\begin{array}{l}27.77 \\
(22.7)^{\mathrm{bc}}\end{array}$ & $\begin{array}{l}29.22 \\
(22.20)^{\mathrm{c}}\end{array}$ & $\begin{array}{l}27.02 \\
(22.29)^{a}\end{array}$ & $\begin{array}{l}22.27 \\
(22.07)^{a}\end{array}$ & $\begin{array}{l}22.02 \\
(27.72)^{b}\end{array}$ \\
\hline
\end{tabular}

Each value represents mean of 2 replications

Figures in parentheses are arc sin transformation $\operatorname{LSD}(0.02)$

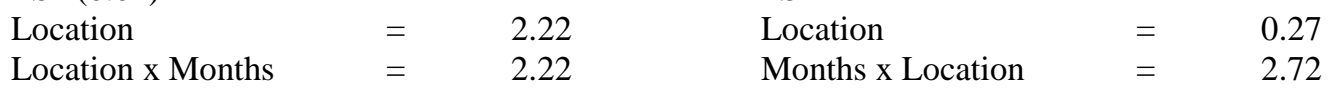

Fig.1 Pattern of maize plant infestation by C. partellus (Swinhoe) during May-July, 2027 in different areas of Kashmir valley

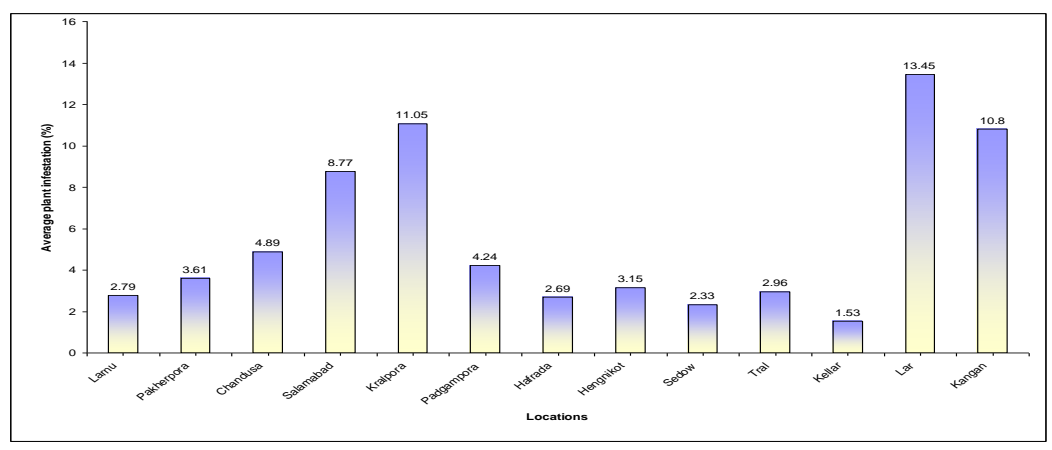

Fig.2 Average incidence of Chilo partellus (Swinhoe) at three hot spot areas of Kashmir during May-October, 2020

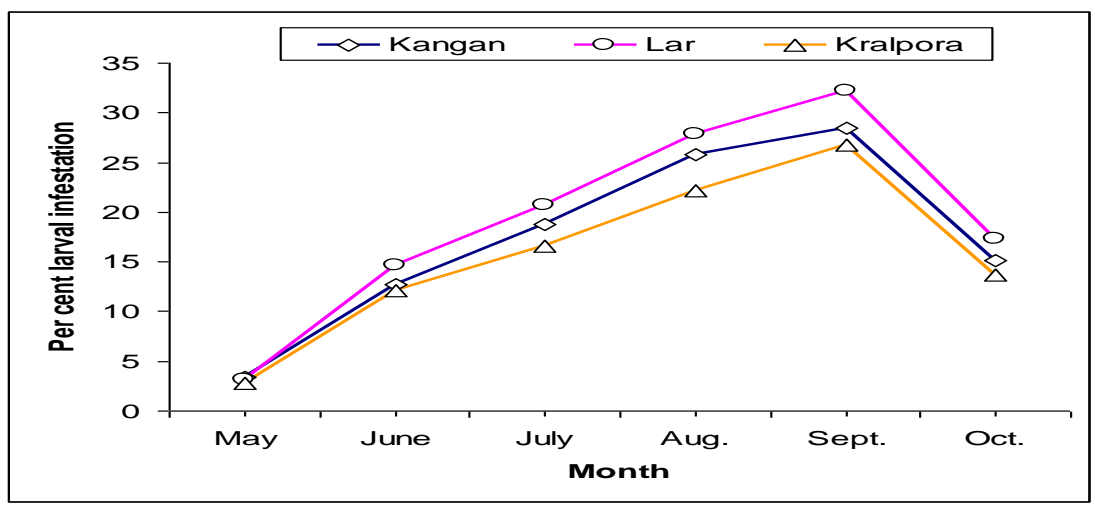


Fig.3 Total incidence (\%) of Chilo partellus at three hot spot areas of Kashmir during JulyOctober' 2019

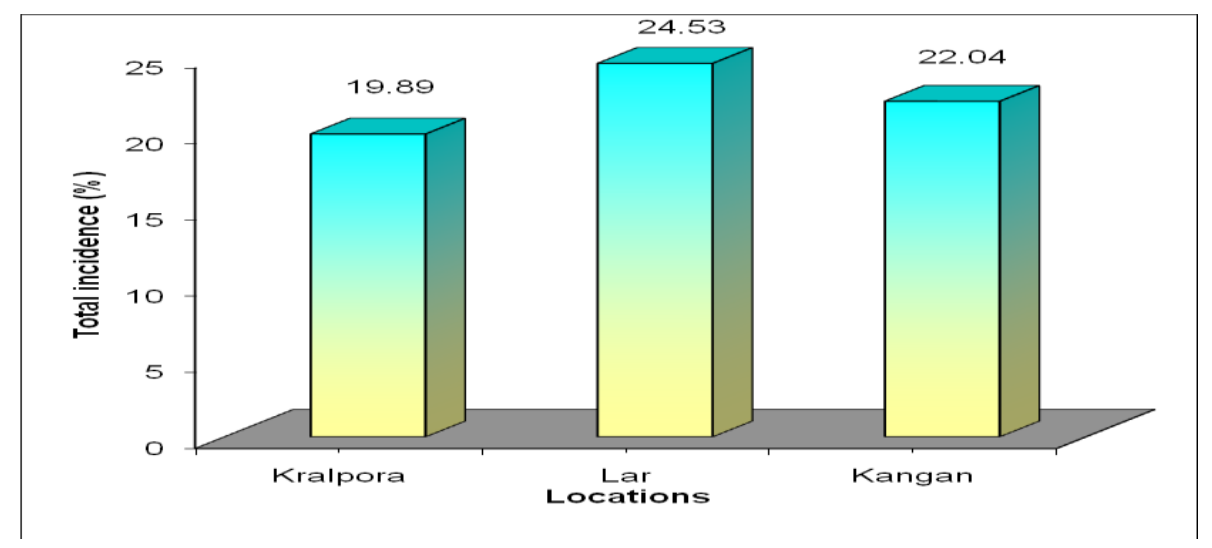

Plate.1 A-G. Examining the presence of Chilo partellus and damage to stalk.A.Checking the damaged plants. B. Pin hole injuries by larva of C. partellus. C. Larva inside whorl. D. Lava in green stalk. E. Larva coming out of exit hole F. Frass out of exit hole. G. Larva in dry stalk
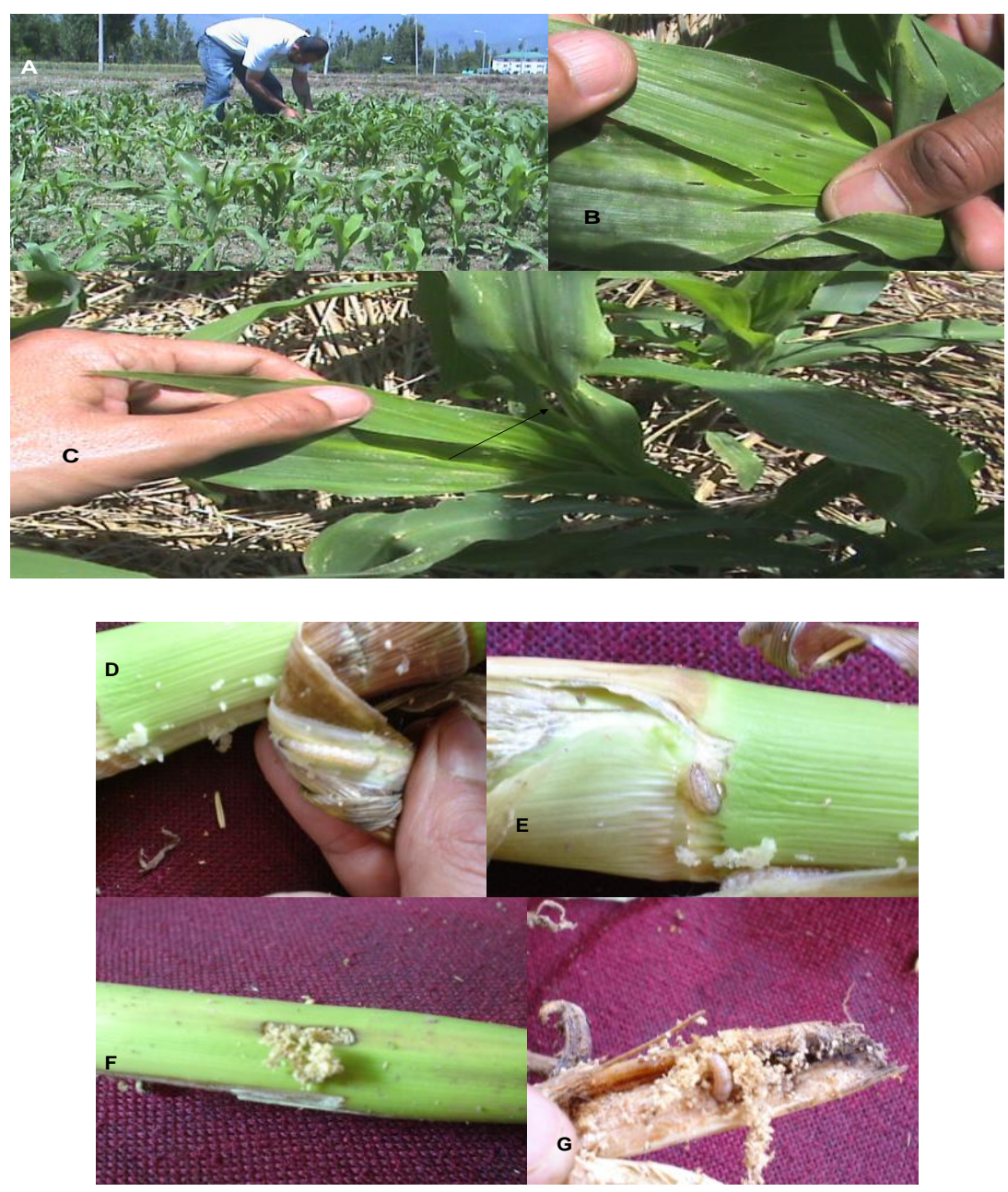
Plate.2 A-B. Different stages of Chilo partellus. A. Fresh egg batch. B. Eggs parasitized by Trichogramma chilonis Ishii C. Mature larva of $C$. partellus D. Pupa inside damaged stalk.E. Enlarged pupa. F. Male (Left), Female (Right)
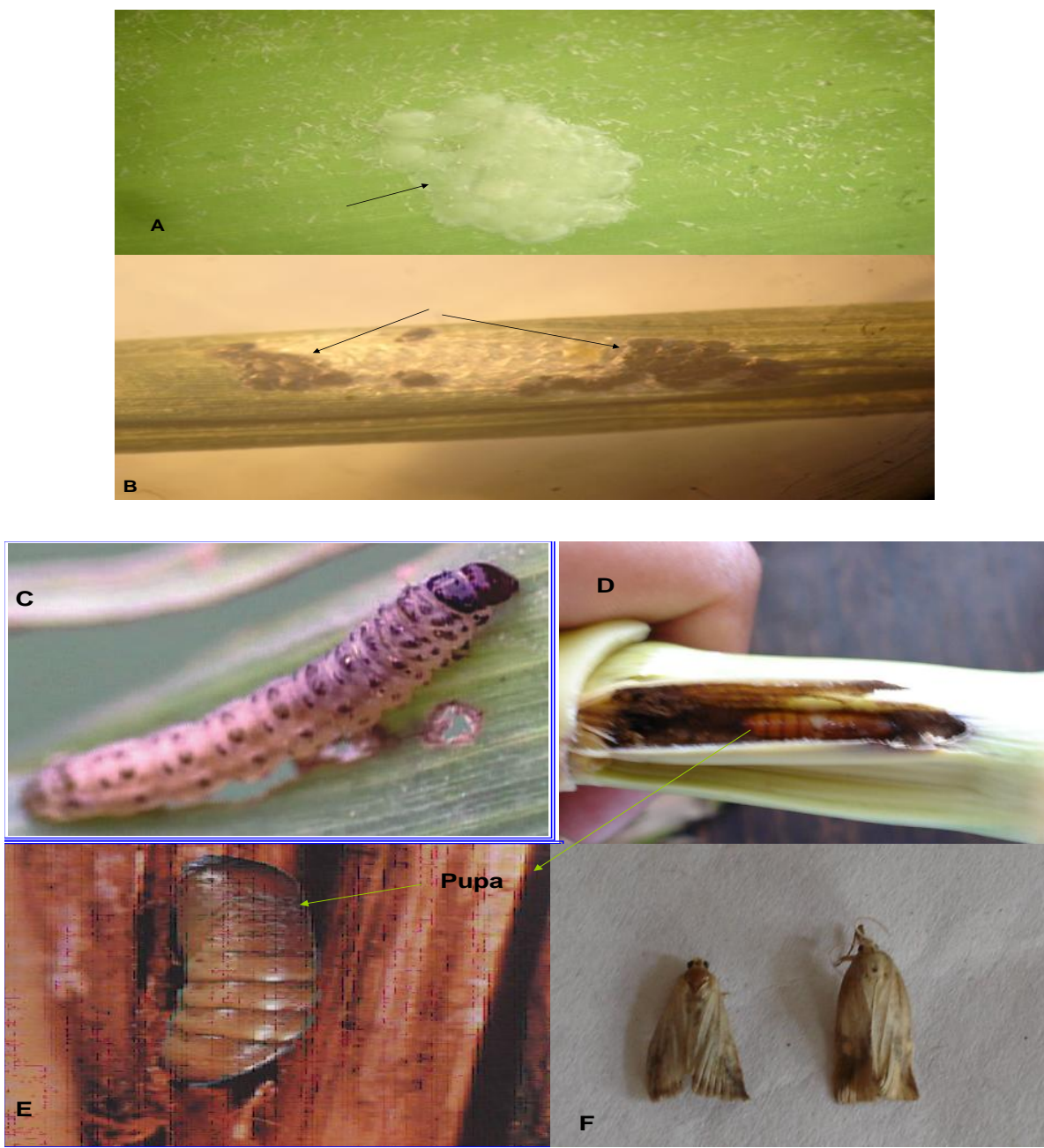

Identification of three different areas showing sufficient level of infestation by maize borer

The present finding revealed Lar and Kangan to favour the C. partellus more as compared to Kralpora (K.D. Farm). Since the latter area falls under SKUAST-K, chemical applications are sometimes done to manage the pest, which resulted into their population decline, as against the former too plots where no chemical application were made. In present study, average maize plant infestation which was found to range 29.77 to 22.22 per cent gets support from earlier finding conducted in the hills of Himachal Pradesh with almost similar climatic conditions (Attri and Sharma, 2977). Geographical conditions of Lar and Kangan, as also mentioned earlier, being a little different from Kralpora (K.D. Farm) showed higher percentage of plant infestation (Table-2). Comparatively higher level of plant damage by the stalk borer in these two areas (undocumented report) may also be due to practising monoculture and dense cropping as observed during the course of the study. Gradual increase in the percentage of plant infestation from July to 
September was due to increased pest density in relation to age of the plant, food availability and other abiotic and biotic factors. Crop age related plant infestation has also been alluded by Chaudhary and Sharma (2990). If control is necessary, contact your state Cooperative Extension Service or click here for control materials and rates.

In present study, highest level of plant infestation was found during second fortnight of September (27-29 $9^{\text {th }}$ week) which later dropped during $20^{\text {th }}-22^{\text {st }}$ week, an almost similar occurrence of high density of plant infestation during $27^{\text {th }}$ week is also reported by Mittal et al., (2006). Gradual increase in plant infestation by borer is also attributable to the use of high level of fertilizer (Nitrogen) by farmers for the purpose of high yield, as has also been documented by Singh and Singh (1979) and Panwar and Sharma (1988).The latter reported increase in per cent plant infestation upto 22.7 per cent in response to Nitrogen@220 kg/ha as compared to 29.7 per cent with no fertilizer at all. Drop in plant infestation after September was due to larval hibernation as also reported by Singh et al., (2972) and Singh and Sharma (1972) from Punjab.

Super infestation of a maize plant during September as revealed by an average of 2.2 to 2.0 larvae/plant (Table-2) was because of larval movements in their $2^{\text {th }}$ to final instar stage, influenced by either high larval density, scarcity of food or decreased food quality (Berger, 1992). Various workers (Berger, 1992; Mittal et al., 2006) believe larval dispersal in $C$. partellus as an adaptive behaviour aimed at enhancing survival of larvae with limited food resource. Since, early sown maize crop in Kashmir valley is harvested during first week of October, late sown crop for fodder therefore provides both food and shelter to hibernating larvae, hence higher density of larvae/plant during
September/October. The number of diapausing larvae/plant was always less than exit holes (Table-2) because of larval dispersal as aforementioned, however, a positive correlation always existed between the two parameters (Fig. 2) i.e. number of residing/hibernating larvae and number of exit holes. If control is necessary, contact your state Cooperative Extension Service or for control materials and rates. Negative correlation between parasitism and maximum temperature, as observed in present case however, is contrary to many earlier findings such as Devi et al., (2997) and Sharma et al., (1988). This is because of an overall decline in maximum temperature at Srinagar from July onwards (barring few cases) whereas increased parasitism during this period which led to observed negative correlation (Table-2) between the above mentioned parameters. Negative correlation between parasitism and rainfall was because of interference of the latter with parasitism, whereas indefinite pattern in period of sunshine hours resulted an overall negative but non-significant correlation (Fig. 3).

In conclusion the present discovery and natural association of Trichrogramma chilonis and Cotesia ruficrus with Chilo partellus is nevertheless an important step necessitating their mass production and future exploitation in the pest prone areas of Kashmir valley. In view of the reported potentials of the above mentioned parasitoids, their augmentative releases right from the last week of May, can result in early suppression of the larval incidence and keep them below economic injury level. Incorporation of these parasitoids as important component of IPM can be both an acceptable and useful tool for farmers. Simultaneously, their natural conservation through judicious and selective use of insecticides, crop residue management, differential period of sowing, staggered harvesting and cropping of alternative host 
plants, etc. can play important role in providing natural refuge to the parasitoids to help their survival for targeted performance against the studied pest in Kashmir valley.

\section{References}

Anonymous, 2019. Statistical Digest (2006-07). Directorate of Economics and Statistics, Planning and Development Department, Govt. of Jammu and Kashmir, Srinagar. pp 94 -97.

Attri, B.S. and Sharma, P.L. 1920. Percentage infestation by Chilo zonellus (Swinhoe): (Lepidoptera:Pyralidae) to maize at different elevations in Himachal Pradesh. Indian Journal of Entomology, 18(3): 317-318.

Baitha, A., Jalali, S.K., Rabindra, R.J., Venketessan, T., Rao, N.S. and Lalitha, Y. 2004. Effect of parasitoid host ratio on some biological attributes of Tetrastichus howardi (Oliff) (Hymenoptera : Eulophidae). Entomon, 29(2): 125-128.

Berger, A. 1992. Larval movements of Chilo partellus (Lepidoptera : Pyralidae) within and between plants: timing, density responses and survival. Bulletin of Entomological Research, 82: 441- 448.

Boucek, Z. 1988. Australasian Chalcidoidea (Hymenoptera). A biosystematic revision of fourteen families with a reclassification of species.CAB International Institute of Entomology. 832 pp.

Chaudhary, R.N. and Sharma, V.K. 1988. Induction and termination of diapause in maize stalk borer, Chilo partellus (Swinhoe). Indian Journal of Entomology, 50(4): 523-529.

Devi, N., Raj, D., Devi, M. and Raj, D. 1996. Extent of parasitisation of on Chilo partellus (Swinhoe) on maize by Apanteles sp. in mid hill zone of Himachal Pradesh (India). Journal of Entomological Research, 20 (2): 171172.

Dicke, F.F. and Guthire, W.D. 1999. The most important corn insects, pp 767-867. In: Corn Improvement. American Society of Agronomy, Madison, W.I.

Mittal, V., Ganesh, R. and Prem, K. 2006. Monitoring of insect pest problems on pearl millet. Journal of Entomological Research, 30(1): 33-34.

Sharma, M.L., Odak, S.C. and Pathak, S.C. 1998.Effect of weather parameters on the efficiency of abiotic factors in regulating larval population of Chilo partellus (Swinhoe). Shashpa, 5(2): 159- 164.

Singh, B., Anand, P.K. and Singh, B. 2017.The influence of single temperature on Apanteles flavipes (Cameron) in parasitizing the maize borer, Chilo partellus (Swinhoe). Indian Journal of Ecology, 91: 118-124

Singh, B., Battu, G.S., Dhaliwal, J.S. and Atwal, A.S. 2003. Population studies on the maize borer, Chilo partellus (Swinhoe) in the Punjab. Mode of hibernation and survival of overwintering larvae. Indian Journal of Entomology, 37(2): 132-136.

Singh, T.P. and Singh, R. 1979. Incidence of stem borer Chilo zonellus (Swinhoe) and lodging in Jaunpur variety of maize under different levels of nitrogen. Indian Journal of Entomology, 31(2): 158-169.

Zaidi, P.H. and Singh, N.N. 2020.Stresses on maize in tropics. Directorate of Maize Research, IARI Campus, pp 299-305, New Delhi - 110012.

\section{How to cite this article:}

Rohie Hassan, Showkat Ahmad Dar, Vikas Gupta, Sing Narppath and Anilmiddha. 2021. Survey and Classification of Hymenoptera in Parasitoids in Kashmir Valley and Prevention There. Int.J.Curr.Microbiol.App.Sci. 10(02): 3373-3381. doi: https://doi.org/10.20546/ijcmas.2021.1002.371 